\title{
Molecular population studies of Simulium damnosum s.I. (Diptera: Simuliidae) using a novel interspersed repetitive DNA marker
}

\author{
P. K. FLOOK* \& R. J. POST $\dagger$ \\ Department of Medical Entomology, Liverpool School of Tropical Medicine, Pembroke Place, Liverpool L3 50A, UK \\ and $\uparrow$ Animal Taxonomy Section, Department of Entomology, Wageningen Agricultural University, PO Box 8031, \\ 6700 EH Wageningen, The Netherlands
}

\begin{abstract}
Simulium damnosum s.l, the vector of West African onchocerciasis, has been the target of a major insect control initiative for the past 20 years. However, attempts to study the migration patterns of reinvading infective flies into controlled areas have been restricted by the lack of suitable genetic markers. Here, the results of the first population-level study of $S$. damnosum s.l. using a repetitive DNA marker, pSO11, are presented. Sequence analysis of pSO11 revealed a complex internal pattern of repetition and an open reading frame with 56.8 per cent similarity to a mouse retrotransposon protein. Combined with an interspersed genomic distribution, the internal structure of pSO11 suggested that it represents the $5^{\prime}$ half of a transposable element. The genomic diversity of the sequence was analysed using Southern blot analysis of genomic DNA. Data were collected from 475 individuals from the island of Bioko (in Equatorial Guinea), Cameroon, Côte d'Ivoire and Sierra Leone. The results indicate that pSO11 is useful as an indicator of genomic diversity and that the experimental design used here permits comparison of an approximately random sample of chromosomal loci. Making this assumption, estimates of homozygosity based on pSO11 diversity were used to study interand intraspecific variability. The results indicate that pSO11 is potentially useful for studying population-level processes in $S$. damnosum s.l.
\end{abstract}

Keywords: DNA markers, migration, natural populations, onchocerciasis, repetitive DNA, Simulium damnosum

\section{Introduction}

In West Africa human onchocerciasis is a highly debilitating blinding disease caused by infection with the filarial nematode Onchocerca volvulus. The parasite is transmitted between people by the bloodsucking fly Simulium damnosum sensu lato. However, S. damnosum s.l. is a complex of sibling species which differ in their epidemiological significance (Wilson \& Post, 1994). The riverine, immature stages of the vectors make them particularly good targets for population control (Philippon et al., 1990), and coordinated studies of the biology and systematics of $S$.damnosum s.l. with the epidemiology of the disease have culminated in the World Health Organisation Onchocerciasis Control Pro-

*Present address and correspondence: Zoologisches Institut, Rheinsprung 9, 4051 Basel, Switzerland. E-mail: flook@ubaclu.unibas.ch gramme (OCP). The OCP has attempted to interrupt disease transmission by managing vector populations through treatment of breeding sites with insecticides (Le Berre et al., 1990) and distribution of the drug ivermectin to the human communities.

The OCP has been successful in controlling the disease in many areas, but operations have often been hampered by regular but unexpected natural movements of vectors over hundreds of kilometres to reinvade controlled areas (Baker et al., 1990). The response to these reinvasions has usually been to extend the controlled area, but this is costly in terms of time and resources. Attempts to investigate these problems have been hindered by the practical difficulties of conducting population surveys over large areas of continental West Africa and by a lack of suitable markers to study population genetics in $S$. damnosum s.l. Allozymes have been used for the study of migration rate and gene flow in other groups (Raab \& Kennedy, 1980; Slatkin, 1985), but 
previous studies have failed to uncover sufficiently useful levels of polymorphism in S. damnosum s.l. (Townson et al., 1987).

The paucity of conventional genetic markers in S. damnosum s.l. makes the group an ideal target for molecular techniques. Molecular methods have already been applied to the development of identification of $S$. damnosum s.l. species with some success (Post \& Flook, 1992). Some molecular systematics has also been carried out at the interspecific level in North American blackfly species (Jacobs-Lorena et al., 1988), including comparative sequence analysis of mitochondrial DNA (Xiong \& Kocher, 1993). However, no studies have been undertaken within species and this paper describes the results of the first population-level study of S. damnosum s.l. to use DNA markers.

The specific aims of this work were: (i) to characterize a candidate repetitive DNA probe, pSO11; (ii) to assess its suitability as a genetic marker by generating information on its genomic distribution; and (iii) to apply the probe in an uncomplicated population scenario (compared with most $S$. damnosum s.l. populations) consisting of an allopatric island population in Bioko, Equatorial Guinea. The vectors of onchocerciasis on the island of Bioko consist of a single chromosome form called the Bioko form of the S. squamosum subcomplex, which is itself part of the S.damnosum complex. The Bioko form is endemic, undoubtedly shows some isolation from mainland populations, but the precise degree of isolation is not known and so its specific status remains uncertain. The vagility of the S. squamosum subcomplex is not considered as high as those species which normally inhabit the savannahs (Garms \& Walsh, 1987).

\section{Materials and methods}

\section{Collection and preservation of material}

Larvae were collected in Carnoy's solution for cytotaxonomic identification. Pupae available from 10 collections at nine sites were kept in a dark humid cage at room temperature until adults emerged. The neonate adults were preserved in 100 per cent ethanol and stored at $4^{\circ} \mathrm{C}$ (Post et al., 1992). A single sample (number 3 ) of biting adult female flies was collected at human bait and also stored in ethanol. Sites are listed in Table 1 and locations indicated on Fig. 1. For comparisons additional collections were used.

1 Three samples of S. squamosum s.str. neonates from Cameroon (sample numbers 10, 11 and 12, respectively). These specimens were identified by correlated larval cytotaxonomy. The taxonomic status of the Bioko form is not yet clear (authors' unpubl. data), but even if the Bioko form is not the same species as S. squamosum they are geographically and taxonomically close within the S. squamosum subcomplex.

2 Two samples of neonates from the S. sanctipauli subcomplex identified by correlated cytotaxonomy: a mixed sample of $S$. soubrense/S. leonense from River Rokel at Makpankaw, Sierra Leone $\left(8^{\circ} 44^{\prime} \mathrm{N}\right.$, $11^{\circ} 56^{\prime} \mathrm{W}$ ) (sample number 13 ), and a sample of S. sanctipauli from River Sassandra at Koperagui, Côte d'Ivoire $\left(5^{\circ} 38^{\prime} \mathrm{N}, 6^{\circ} 38^{\prime} \mathrm{W}\right)$ collected by M. D. Wilson.

\section{Sequencing of pSO11}

The repetitive DNA probe pSO11 was originally isolated from an S.leonense genomic DNA library for its potential use in sibling species identification (Post \& Flook, 1992). The $3.27 \mathrm{~kb}$ EcoRI insert of pSO11 was digested with restriction enzymes, transferred to a nitrocellulose membrane by Southern blotting and hybridized with radiolabelled genomic DNA. Analysis of the autoradiographs indicated that the repetitive region of the clone was confined to a $1.37 \mathrm{~kb}$ Eco RI/HindIII fragment. This fragment was isolated, digested with $A l u \mathrm{I}$ and HaeIII restriction endonucleases and subcloned into M13. The subfragments were sequenced on both strands using the Sanger dideoxy method (Sanger et al., 1977). The pSO11 sequence was assembled from the partial sequences and analysed using the GCG package (Devereux et al., 1984). The final sequence has been deposited in the EMBL data library with the accession number X70645.

\section{Genomic DNA extraction and restriction digestion}

DNA was extracted from individual flies using a previously described protocol (Flook et al., 1992). The DNA was ethanol precipitated three times, resuspended in a final volume of $15 \mu \mathrm{L}$ of TE $(10$ $\mathrm{mm}$ Tris-HCl, 1 mм EDTA, pH 8.0)+RNase $\left(50 \mathrm{mg} \mathrm{mL}^{-1}\right)$ and stored at $-20^{\circ} \mathrm{C}$. Genomic DNA was digested with EcoRI at a low concentration

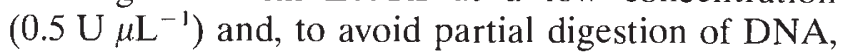
reactions were incubated overnight at $37^{\circ} \mathrm{C}$. In a random sample of membranes, probe DNA was stripped and new hybridizations performed with a mosquito ribosomal RNA probe, AaR1 (Gale \& Crampton, 1989). This probe hybridizes to a single EcoRI fragment in S. damnosum s.l. and conse- 
Table 1 Results of pSO11 Southern hybridization analysis of individual flies from different species and localities. Figures are calculated from pSO11 hybridizing fragments in the size range 3.27-0 kb. For collection details see text. Distance values were calculated only between samples on the same autoradiograph, and so for some populations more than one average pairwise similarity (APS) value was calculated. Results are not shown for the $S$. sanctipauli population from Côte d'Ivoire because the samples were run on a number of different gels and no direct comparisons comprising sufficient individuals were available from which to calculate APS values. Coll. No, refers to the collection number for a given site. Season refers to whether the sample was collected in the first trip at the end of the dry season (in May) or in the second, at the beginning of the rainy season (in November). $\Sigma \mathrm{H}=$ number of different haplotypes observed; $\Sigma \mathrm{B}=$ number of different band sizes observed; $\mathrm{AvH}=$ Average number of haplotypes $(=\Sigma \mathrm{H} / n)$; APS $=$ average pairwise similarity; MAPS $=$ mean average pairwise similarity $(=\Sigma$ APS $/ \mathrm{NS}$, where NS = number of samples)

\begin{tabular}{|c|c|c|c|c|c|c|c|c|}
\hline Coll. No. & Season & Co-ordinates & $n$ & $\Sigma H$ & $\Sigma \mathrm{B}$ & $\mathrm{AvH}$ & APS & MAPS \\
\hline \multicolumn{9}{|l|}{ Bioko } \\
\hline 1 & Rainy & $3^{\circ} 23^{\prime} \mathrm{N}, 8^{\circ} 46^{\prime} \mathrm{E}$ & 10 & 8 & 11 & 0.8 & 35.3 & 35.3 \\
\hline 2 & Rainy & $3^{\circ} 28^{\prime} \mathrm{N}, 8^{\circ} 35^{\prime} \mathrm{E}$ & $\begin{array}{l}21 \\
12 \\
12\end{array}$ & $\begin{array}{r}15 \\
10 \\
9\end{array}$ & $\begin{array}{r}11 \\
9 \\
7\end{array}$ & $\begin{array}{l}0.7 \\
0.8 \\
0.8\end{array}$ & $\begin{array}{l}13.7 \\
15.3 \\
17.1\end{array}$ & \\
\hline 3 & Rainy & $3^{\circ} 34.5^{\prime} \mathrm{N}, 8^{\circ} 37^{\prime} \mathrm{E}$ & $\begin{array}{l}21 \\
22 \\
25 \\
26 \\
12\end{array}$ & $\begin{array}{l}17 \\
15 \\
19 \\
21 \\
11\end{array}$ & $\begin{array}{r}15 \\
13 \\
14 \\
16 \\
8\end{array}$ & $\begin{array}{l}0.8 \\
0.7 \\
0.8 \\
0.8 \\
0.9\end{array}$ & $\begin{array}{r}10.7 \\
8.6 \\
19.8 \\
13.7 \\
12.3\end{array}$ & $15.4 \pm 1.7$ \\
\hline 4 & Dry & $3^{\circ} 30.5^{\prime} \mathrm{N}, 8^{\circ} 36.5^{\prime} \mathrm{E}$ & $\begin{array}{l}6 \\
9\end{array}$ & $\begin{array}{l}6 \\
8\end{array}$ & $\begin{array}{r}27 \\
9\end{array}$ & $\begin{array}{l}1.0 \\
0.9\end{array}$ & $\begin{array}{l}23.8 \\
14.4\end{array}$ & $13.0 \pm 4.2$ \\
\hline 5 & Rainy & $3^{\circ} 37.5^{\prime} \mathrm{N}, 8^{\circ} 37.5^{\prime} \mathrm{E}$ & 11 & 11 & 8 & 1.0 & 22.0 & $\begin{array}{l}19.1 \pm 6.6 \\
22.0\end{array}$ \\
\hline 6 & Dry & $3^{\circ} 41^{\prime} \mathrm{N}, 8^{\circ} 39^{\prime} \mathrm{E}$ & $\begin{array}{l}14 \\
11\end{array}$ & $\begin{array}{r}7 \\
11\end{array}$ & $\begin{array}{r}12 \\
9\end{array}$ & $\begin{array}{l}0.5 \\
1.0\end{array}$ & $\begin{array}{r}9.2 \\
17.1\end{array}$ & 22.0 \\
\hline 7 & Rainy & $3^{\circ} 41^{\prime} \mathrm{N}, 8^{\circ} 39^{\prime} \mathrm{E}$ & $\begin{array}{l}24 \\
25 \\
12\end{array}$ & $\begin{array}{r}15 \\
14 \\
7\end{array}$ & $\begin{array}{l}13 \\
11 \\
11\end{array}$ & $\begin{array}{l}0.6 \\
0.6 \\
0.6\end{array}$ & $\begin{array}{r}19.3 \\
17.3 \\
5.6\end{array}$ & $14.1+7.4$ \\
\hline 8 & Rainy & $3^{\circ} 41^{\prime} \mathrm{N}, 8^{\circ} 39.5^{\prime} \mathrm{E}$ & $\begin{array}{r}6 \\
10\end{array}$ & $\begin{array}{r}6 \\
10\end{array}$ & $\begin{array}{r}7 \\
12\end{array}$ & $\begin{array}{l}1.0 \\
1.0\end{array}$ & $\begin{array}{l}25.0 \\
19.7\end{array}$ & $22.4+3.7$ \\
\hline 9 & Rainy & $3^{\circ} 43^{\prime} \mathrm{N}, 8^{\circ} 43.5^{\prime} \mathrm{E}$ & $\begin{array}{c}11 \\
8 \\
6 \\
\Sigma=314\end{array}$ & $\begin{array}{r}11 \\
5 \\
4\end{array}$ & $\begin{array}{r}13 \\
7 \\
3\end{array}$ & $\begin{array}{l}1.0 \\
0.6 \\
0.7\end{array}$ & \begin{tabular}{r|}
11.9 \\
26.0 \\
22.2 \\
\\
17.3
\end{tabular} & $20.0 \pm 7.3$ \\
\hline $\begin{array}{l}\text { Cameroon } \\
10\end{array}$ & Dry & $4^{\circ} 37^{\prime} \mathrm{N}, 9^{\circ} 21^{\prime} \mathrm{E}$ & 16 & 15 & 20 & 0.9 & 17.8 & 178 \\
\hline 11 & Dry & $4^{\circ} 43^{\prime} \mathrm{N}, 9^{\circ} 29^{\prime} \mathrm{E}$ & $\begin{array}{l}12 \\
12\end{array}$ & $\begin{array}{l}11 \\
10\end{array}$ & $\begin{array}{l}16 \\
12\end{array}$ & $\begin{array}{l}0.9 \\
0.8\end{array}$ & $\begin{array}{l}9.0 \\
8.3\end{array}$ & $8.7+0.5$ \\
\hline 12 & Dry & $4^{\circ} 43^{\prime} \mathrm{N}, 9^{\circ} 29^{\prime} \mathrm{E}$ & $\begin{array}{l}13 \\
22\end{array}$ & $\begin{array}{l}13 \\
21\end{array}$ & $\begin{array}{l}28 \\
25\end{array}$ & $\begin{array}{l}1.0 \\
1.0\end{array}$ & $\begin{array}{l}15.6 \\
11.4\end{array}$ & \\
\hline & & & $\Sigma=75$ & & & & 12.4 & \\
\hline $\begin{array}{l}\text { Sierra Leone } \\
13\end{array}$ & Rainy & $8^{\circ} 44^{\prime} \mathrm{N}, 11^{\circ} 56^{\prime} \mathrm{W}$ & $\begin{array}{l}11 \\
12 \\
25\end{array}$ & $\begin{array}{l}10 \\
12 \\
25\end{array}$ & $\begin{array}{l}24 \\
21 \\
38\end{array}$ & $\begin{array}{l}0.9 \\
1.0 \\
1.0\end{array}$ & $\begin{array}{l}53.1 \\
56.6 \\
45.2\end{array}$ & \\
\hline & & & $\Sigma=48$ & & & & 51.6 & $51.6 \pm 5.8$ \\
\hline
\end{tabular}


quently complete digestion of genomic DNA could be confirmed.

\section{Agarose electrophoresis and Southern blotting}

Agarose gels (0.9 per cent, FMC SeaKem) were prepared using $1 \times$ TAE buffer $(40 \mathrm{~mm}$ Tris-acetate, $1 \mathrm{mM} \mathrm{Na}$.EDTA) and run overnight at $<2 \mathrm{~V} \mathrm{~cm}^{-1}$. Postelectrophoresis, gels were prepared for Southern blotting by denaturation and neutralization (Southern, 1975; Sambrook et al., 1989). Limited exposure to ultraviolet light on a transilluminator was used to depurinate the DNA prior to denaturation (FMC-Bioproducts, 1990). DNA was transferred to nitrocellulose filters (Biotrace NT) by capillary transfer.

\section{Hybridization}

Insert DNA from EcoRI-digested pSO11 was recovered from agarose gels and radiolabelled with $\left[\alpha-\mathrm{P}^{32}\right]$-dCTP using random-primed labelling. Filters were prehybridized in $(5 \times \mathrm{SSC}, 50$ per cent deionized formamide, $5 \times$ Denhardt's, $0.05 \mathrm{~m}$ phosphate buffer, $50 \mathrm{mg} \mathrm{mL}^{-1}$ denatured herring sperm DNA) at $42^{\circ} \mathrm{C}$ in prehybridization solution $\left(5 \mathrm{~mL} 100 \mathrm{~cm}^{-2}\right.$ filter) and the buffer was exchanged for fresh buffer $(5 \times \mathrm{SSC}, 50$ per cent deionized formamide, $5 \times$ Denhardt's, $0.02 \mathrm{~m}$ phosphate buffer, $100 \mathrm{mg}$ $\mathrm{mL}^{-1}$ denatured herring sperm DNA) immediately before hybridization. Labelled probe was denatured by heating to $100^{\circ} \mathrm{C}$ and added at a concentration of $1 \times 10^{7}-5 \times 10^{8}$ c.p.m. $100 \mathrm{~cm}^{-2}$. All hybridization reactions were continued overnight at $42^{\circ} \mathrm{C}$ in a hybridization oven. Filters were washed in various concentrations of SSC, 0.1 per cent SDS at different temperatures and exposed to Fuji RX film at $-45^{\circ} \mathrm{C}$ or $-70^{\circ} \mathrm{C}$.

\section{Data analysis}

The observed banding profiles for pSO11 were so variable that an appropriate statistic for the comparison of different specimens was a similarity

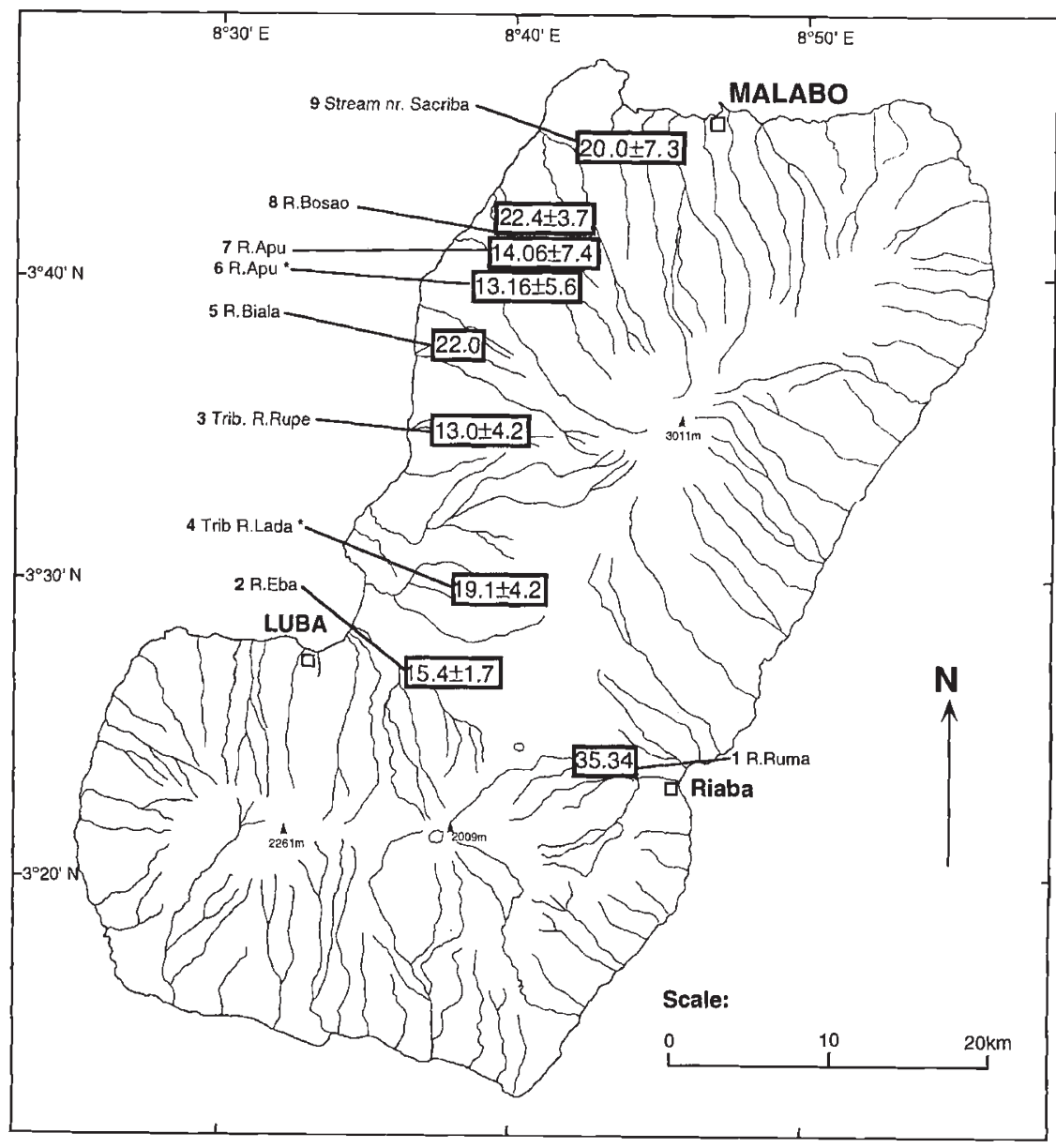

Fig. 1 Map of Bioko indicating mean average pairwise distance values (MAPDs) and standard errors (where more than one APD was available) for the different collecting sites. MAPDs were only calculated for sites where sufficient numbers of pupae were collected. Asterisks indicate samples collected in the dry season. 
coefficient and in this study the DNA-fingerprint similarity index, $S$ (Lynch \& Crease, 1990; Yuhki \& O'Brien, 1990), was used. For two individuals $i$ and $j$ the index is calculated as

$S_{i j}=\frac{2 F_{i j}}{F_{i}+F_{j}}$,

where $F_{i}$ and $F_{j}$ are the numbers of bands in each individual, and $F_{i j}$ is the number of shared bands. To summarize the similarity between large numbers of individuals, this statistic is extended to cover all pairwise comparisons and is referred to here as the average pairwise similarity (APS), where for $i<j$ and $N$ is the population size

APS $=\frac{1}{\left(\begin{array}{c}N \\ 2\end{array}\right)} \sum_{i}^{N} \sum_{j}^{i} S_{i j} \times 100$.

This statistic essentially treats the banding patterns as phenotypic characters and does not directly estimate important genetic parameters. It ranges from 100 (complete identity) to 0 (complete dissimilarity).

Although both statistics could be calculated unambiguously for individual specimens run on the same gel, it was more difficult to estimate them among individuals on different gels because of the problem of identifying homologous bands. This precluded the direct comparison of discrete bands from individual DNA samples size-fractionated on different gels and consequently the comparison of different populations by standard parameters such as $G_{\mathrm{ST}}$ was not possible in this study. Instead, values of APS were calculated for individuals from the same population run on the same gel, and the indices compared between populations. For populations where more than one filter was available, the mean APS (MAPS) was also calculated.

\section{Results}

\section{Characterization of $p S 011$}

The sequence of the pSO11 HindIII/EcoRI fragment was 67.7 per cent $A+T$ and dot matrix analysis revealed a complex pattern of repetition, consisting of two adjacent sets of repeats (Fig. 2). First, three tandem repeats with a consensus length of $276 \mathrm{bp}$ (LR1, LR2 and LR3) were detected at the $5^{\prime}$ end of the sequence. No internal pattern of repetition could be detected within these repeats. Differences were detected between the repeats at 64 positions (23.2 per cent), although a significant amount of this heterogeneity was accounted for by a 25 bp deletion

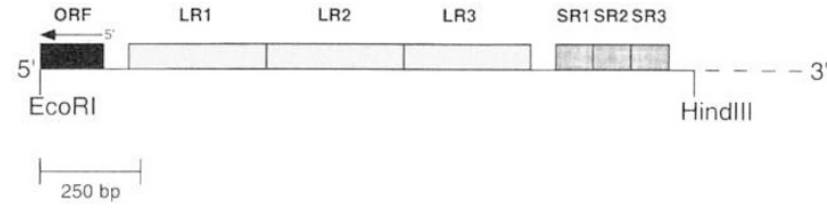

Fig. 2 Gene map of pSO11. The dashed line corresponds to the beginning of the unsequenced $3^{\prime}$ region of the original pSO11 EcoRI insert. LR1, LR2 and LR3 correspond to the positions of three $276 \mathrm{bp}$ repeats. SR1, SR2 and SR 3 correspond to the positions of three $63 \mathrm{bp}$ repeats. ORF indicates the position of the open reading frame discussed in the text and the arrow indicates the sense of the ORF.

in LR2. Secondly, three tandem repeats of length $63 \mathrm{bp}$ (SR1, SR2 and SR3) were identified $8 \mathrm{bp}$ downstream of the $3^{\prime}$ end of LR3. These repeats were 12 per cent heterogeneous and showed some similarity to the $5^{\prime}$ region of the $276 \mathrm{bp}$ repeats. The unsequenced and nonrepetitive region of pSO11 was downstream of SR3.

A search was made for open reading frames (ORFs) located in the nonrepetitive regions of the sequence and a $152 \mathrm{bp}$ candidate was found upstream of LR1 (see Fig. 1). The $3^{\prime}$ end of the ORF coincided with the $5^{\prime}$ end of the complete pSO11 fragment and no further sequence could be obtained. This sequence was translated and used to search the PROSITE sequence database with the PROSRCH program (Collins \& Coulson, 1987). Among several similarities found was a match to the $\mathrm{C}$ terminal end of an $\mathrm{L} 1$ retrotransposon protein sequence from Mus domestica (Loeb et al., 1986). The L1 and pSO11 ORF sequence amino acid sequences were aligned and found to share 17.6 per cent identity ( 56.8 per cent similarity).

As a second stage of its characterization, the genomic distribution of pSO11 was analysed by Southern blot analysis of a limited number of individual flies. Using restriction enzymes that did not cut the repetitive region of the pSO11 clone (EcoRI, HindIII, HaeIII), genomic DNA preparations were digested, size-fractionated on agarose gels and transferred to nitrocellulose membranes. Filters were hybridized with radiolabelled pSO11 as described under Materials and methods. Similar banding profiles were generated for the different restriction enzymes, consisting of multiple $(30-50)$, discrete hybridizing fragments of uniform intensity. These patterns also varied between individuals and are consistent with an interspersed repetitive distribution of pSO11. If copies of the repeat were localized 
in the genome, for example if pSO11 belonged to a family of clustered tandem repetitive DNA, or was a rare mobile element inserted within a region of clustered repetitive DNA, distributions of band sizes would be expected to be relatively uniform. Taken together, the information concerning the sequence and genomic distribution of the pSO11 $H i n \mathrm{dIII} / E c o$ RI fragment strongly suggests that it is the $5^{\prime}$ half of a transposable element.

\section{Size distribution of pSO11 hybridizing EcoRI fragments}

To examine the genomic distribution of pSO11 in more detail, 475 EcoRI-digested nuclear DNA samples from individual flies were examined in Southern blot hybridizations. In the resulting autoradiographs, the lengths of different hybridizing fragments were interpreted as corresponding to the distance between the internal EcoRI site of a pSO11 hybridizing fragment and the nearest adjacent EcoRI site in the flanking genomic DNA at the insertion site. If pSO11 is a transposable element and is randomly inserted into different regions of the genome, the distribution of pSO11 hybridizing EcoRI fragment sizes should therefore approach the distribution for all EcoRI genomic DNA fragments. To examine this prediction, the distribution of the sizes of pSO11 hybridizing fragments was compared with the distribution of EcoRI fragment sizes estimated from densitometer scans of ethidium bromide stained genomic smears. Only fragments smaller than $3.27 \mathrm{~kb}$ were included because a hybridizing band of this size occurred at high frequency in the Bioko population and served as a convenient marker on the gels. Also, because the number of bands greater than $3.27 \mathrm{~kb}$ was very high (see Fig. 3), the hybridization was usually too intense to score bands accurately. A graph summarizing the results is presented in Fig. 4 and the plots show that the cumulative distribution of pSO11 fragment sizes is very similar to that obtained for the EcoRI-digested genomic DNA fragments.

A problem arises in the comparison of these cumulative distributions of fragment size because the pSO11 distribution is biased owing to the presence of the $1.37 \mathrm{~kb}$ pSO11 copy in all fragments. This decreases the probability that an EcoRI site will occur within the first $1.37 \mathrm{~kb}$ of an EcoRI fragment containing a copy of pSO11. However, because this probability will be the same in all pSO11 hybridizing fragments the observed similarity in the shape of the distributions indicates that the distance between the end of pSO11 copies and adjacent EcoRI repeats is

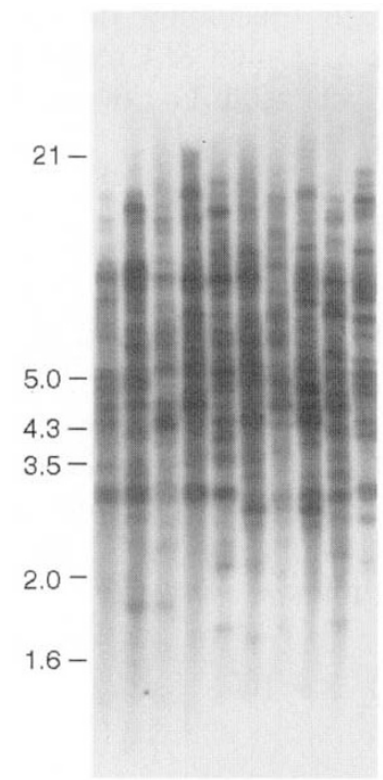

Fig. 3 Autoradiograph showing the hybridization pattern of ${ }^{32}$ P-labelled pSO11 probe to individual EcoRI-digested, individual fly DNA preparations. Restriction fragments were size-fractionated on a 0.9 per cent $1 \times$ TAE agarose gel. Figures refer to the size of molecular weight marker bands in $\mathrm{kb}$.

distributed in a similar way to EcoRI sites in the entire genome. It follows from this observation that the chromosomal distribution of the pSO11 sequences is random with respect to the distribution of EcoRI recognition sites.

\section{Estimation of copy numbers}

Taking the distribution of pSO11 to be approximately random, the samples of hybridizing EcoRI fragments measured in the different individuals constitute random samples from which it should be possible to make an estimate of relative copy number between species. Thus, the distribution of band numbers in individuals of different species was examined in our sample and the number of bands in different size categories (within the range $0-3.7 \mathrm{~kb}$ ) averaged across all samples within species. The results are summarized in Table 2 and the estimated copy numbers relative to $S$. squamosum Bioko were 1.5 in the Cameroon $S$. squamosum, 3.1 in S. sanctipauli s.str and 4.4 in $S$. soubrense/S. leonense. Although these estimates can only be very approximate, the apparent equality of band numbers between the two S. squamosum s.l. taxa, and the increased numbers in S. sanctipauli and S. soubrense, 
both concur with the results of various hybridization analyses which suggest that the copy number of pSO11 is species-specific (authors' unpubl. data). This observation is important because it is possible that changes in the structure of pSO11 in different host genomes might bias the distribution of observed fragment sizes between species. Because there is a degree of correspondence between melting curve estimates of copy number and estimates derived here, this could be taken as a further indication of the randomness of the $0-3.27 \mathrm{~kb}$ sample of pSO11 hybridizing fragments.

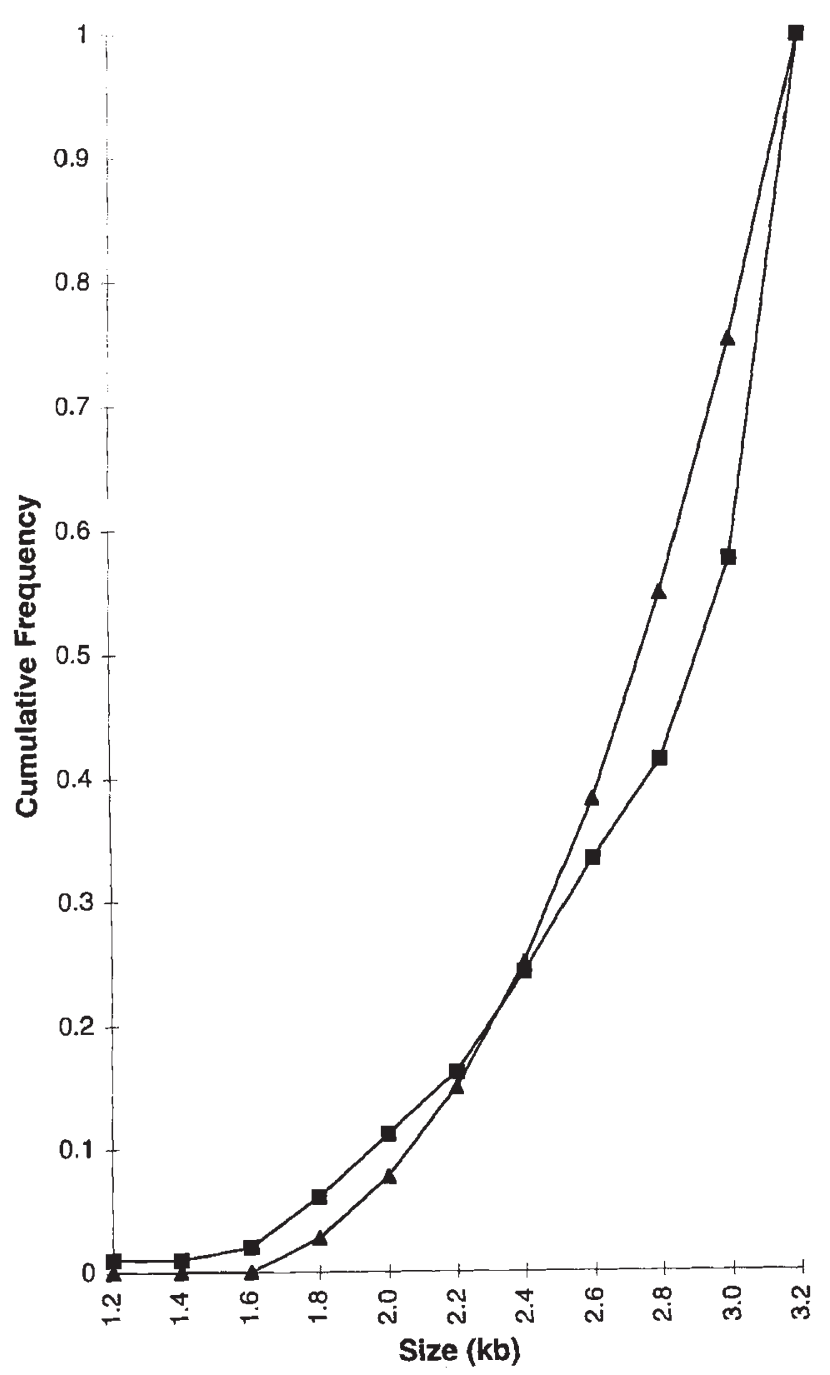

Fig. 4 Comparison of observed cumulative frequencies of pSO11 hybridizing fragment sizes and EcoRI-digested $S$. squamosum Bioko genomic DNA smear. Only bands in the range $0-3.2 \mathrm{~kb}$ were scored. $\Delta=E c o \mathrm{RI}$-digested genomic DNA fragments; $\mathbf{\square}=$ pSO11 hybridizing $E c o$ RI fragments.

(C) The Genetical Society of Great Britain, Heredity, 79, 531-540.

\section{Interspecific variation in banding and heterozygosities}

The APS estimates for the Bioko, Cameroon and Sierra Leone populations are presented in Table 1. As a preliminary step, the relationship between sample size and APS was examined by calculating the product-moment correlation coefficient for these two variables. A negative correlation of 0.33 was obtained but this correlation was not statistically significant $(P=0.13)$ indicating that the APS values were independent of sample size.

The highest intraspecific APS values were observed in the Sierra Leone population (sample 13) and the difference between these APS values and the Cameroon and Bioko S. squamosum s.l. was statistically significant (unpaired $t$-test, $P<0.01$ ). Differences were also apparent between the $S$. squamosum subcomplex samples with the Cameroon samples demonstrating considerably lower APS values (MAPS $=12.42$ ) than the Bioko populations (MAPS =17.27). However, this difference was not statistically significant at the 5 per cent level. Hence, if the assumption that pSO11 is an unbiased indicator of genomic diversity holds, and its mobility is similar in these taxa, the results imply that the Cameroon sample is no more heterozygous than the Bioko sample.

\section{Bioko form intrapopulation variation}

The results of the intrapopulation surveys are presented in Table 1 and differences in APS values calculated for the different populations can be detected. Figure 1 shows the distribution of the MAPS values of different Bioko populations. The MAPS for different populations collected in the rainy season ranged from $13.02 \pm 4.7$ (sample 3) to 35.3 (sample 1). Comparing the MAPS values using $t$-tests, some of the estimates of variability were statistically significant $(P<0.05)$ between samples collected in the rainy season; for example, using this approach, MAPS values between samples 2 and 8 and samples 3 and 8 were found to be significantly different. However, in two of the samples (7 and 9) the standard errors of the MAPSs were particularly high and so differentiation was not shown to be statistically significant in most comparisons.

\section{Discussion}

\section{Interspecific variation}

Two kinds of interspecific variation were identified in the present study. First, interspecific variation in 
Table 2 Average numbers of pSO11 bands. For collection and experimental details see main text. Figures refer to average number of pSO11 hybridizing fragments in the size range $3.27-0.0 \mathrm{~kb}$. The copy numbers are calculated relative to $S$. squamosum Bioko. In S. squamosum Bioko files, the $3.27 \mathrm{~kb}$ high frequency band was not included in calculations. In $S$. sanctipauli subcomplex flies two high frequency hybridizing fragments, $2.3 \mathrm{~kb}$ and $0.8 \mathrm{~kb}$ bands, are included in the calculation

\begin{tabular}{lcccc}
\hline Species & $n$ & $\begin{array}{c}\text { Average } \\
\text { band number }\end{array}$ & SD & $\begin{array}{c}\text { Relative } \\
\text { copy number }\end{array}$ \\
\hline S. squamosum Bioko & 334 & 1.37 & 1.12 & 1.0 \\
S. squamosum Cameroon & 75 & 2.10 & 1.42 & 1.5 \\
S. sanctipauli s.l. & 18 & 4.22 & 1.48 & 3.1 \\
S. soubrense/S. leonense & 48 & 6.00 & 1.22 & 4.4 \\
\hline
\end{tabular}

copy number was observed. Such variation had been previously observed in quantitative hybridization analyses (Post \& Flook, 1992) and the estimates obtained here coincide well with those results. Secondly, large differences were noted in the APS values recorded for the different taxa examined in this study. Notably, the $S$. sanctipauli subcomplex sample from Sierra Leone showed far less diversity than the two S. squamosum s.l. samples. The significance of this observation is difficult to interpret because the $S$. sanctipauli s.l. sample is unrelated to the other two. However, it is notable that the Makpankaw population was very large and so the low level of population diversity recorded was unexpected. It is possible that species of the $S$. sanctipauli subcomplex simply showed less genomic diversity than the other two taxa. They are not thought to be strongly migratory and breed in large rivers, which might be considered ecologically more uniform. It is also possible that this particular population may show reduced diversity as a result of some unknown founder effect such as recolonization after the dry season or insecticide treatment. A third explanation for the low variability might be connected to the genomic distribution of pSO11. As the pSO11 copy number is much higher for the two species sampled here, the pSO11 sequence might be approaching saturation level in the genome. Observations on transposable elements in other species indicate that deterministic forces counter the spread of elements (Charlesworth \& Langley, 1989) and that the mobility of sequences is often decreased as copy numbers approach a limiting value.

In contrast to the above, the lack of difference in the level of diversity between the two $S$. squamosum subcomplex populations is interesting. Cytogenetic analyses of the $S$. squamosum Bioko population have clearly identified some degree of genetic isolation from the mainland populations in Cameroon (Post et al., 1997), and field observations during the collecting trips indicate large seasonal fluctuations in population size. Under these circumstances, population bottlenecks and decreased genetic variability might be predicted in the $S$. squamosum Bioko populations, resulting in decreased genetic variability compared to the Cameroon populations. However, the similarity of the APS between Bioko and Cameroon populations may indicate that the underlying processes of population colonization and extinction are actually very similar.

\section{Structure of the Bioko S. damnosum s.l. population}

One of the aims of this study was to make inferences about the population structure of the Bioko S. squamosum and in this respect the results were able to provide information about specific features of the Bioko population; for example, the high APS value for sample 1 from River Ruma is notable because it was from the eastern side of the island where very few potential breeding sites were observed. Simulium damnosum s.l. is not recorded either biting or breeding from the middle of the island and it is likely that the two sides show some degree of isolation. The relative homogeneity of this population suggests that it is smaller and more inbred, a situation consistent with these observations. In contrast, sample 3 showed the highest level of variability. This sample consisted of adult females caught at human bait, and is probably a mixture of flies emerging from a number of sites, including different rivers. Appetitive dispersal of flies (coming to humans for a blood-meal) was frequently observed between rivers, and thus a sample of wild-caught, adult females

(c) The Genetical Society of Great Britain, Heredity, 79, 531-540. 
might be expected to be more heterogeneous. Therefore, both these observations are significant because they represent situations where there exists a strong expectation concerning the population variability, and where levels of pSO11 diversity concur with that expectation.

Also of interest were the comparative MAPS values estimated for the populations sampled in the rainy season $(1-3,5,7-9)$ where there is weak evidence for a decrease in variability in the more northerly populations compared to those further south on the west side of the island. This was initially examined by ranking populations according to their latitude and MAPSs, and computing the Spearman rank correlation, but no significant correlation was detected $(P>0.1)$. However, using $t$-tests to compare MAPS estimates, significant differences were detected between the most southern population (sample 2) and two northern populations (samples 8 and 9). Any trend linking variability with latitudinal position is potentially important if real because it would be consistent with a northward recolonization of the island from perennial rivers in the south as the seasonal rivers begin to flow after the dry season. Such behaviour would have important consequences for population control, because sites in the south of the island would become obvious targets for larvicidal treatment. However, it is evident from inspecting the geographical distribution of collection data (Fig. 1) that more extensive population sampling is needed to explore this possibility in detail.

\section{Suitability of pSO11 as a population genetic marker}

The results of this study showing pSO11 to exhibit high levels of intraspecific variability make it a potentially useful marker for future studies of $S$. damnosum population biology. The apparently random chromosomal distribution of pSO11 is of particular importance, because it allows homogeneity in observed pSO11 haplotypes to be equated with population homogeneity. If pSO11 is a transposable element, as the sequence analysis suggests, the above assumption has an experimental precedent in work conducted on Drosophila, where differences between founder populations have been detected using in situ hybridization studies of the $m d g 1$ TE polymorphism (Terzian \& Bièmont, 1988).

A remaining difficulty with the experimental design used here is the statistical treatment of the Southern blot banding profiles. This is a technical problem associated with the identification of homologous bands on different gels. In the field of DNA fingerprinting various solutions to this problem have been developed including analytical approaches ('binning' strategies: Budowle et al., 1991) and novel experimental procedures specifically designed to prevent ambiguous interpretations (Jeffreys et al., 1991). These specific approaches are inappropriate for the pSO11 Southern blot data, but some similar improvement in procedure is necessary to generate reliable estimates of population genetic parameters from pSO11. A potential strategy might be to use PCR to detect inserted copies of pSO11 at specific sites using primers homologous to different chromosomal flanking regions.

\section{Acknowledgements}

The authors are grateful to Dr J. Mas, the Agencia Espanola de Cooperacion Internacional and the Ministerio de Sanidad Guinea Ecuatorial for their assistance, without which the collecting could not have been carried out. In Cameroon, Drs P. Enyong and R. Moyou, and D. Ekale also generously provided accommodation and assistance. Alice Millest provided technical assistance and Mike Wilson provided help and advice with fly identification and PCR. The manuscript was improved by the comments of two anonymous reviewers. The work was funded by the British Medical Research Council.

\section{References}

BAKER, R. H. A., GUlllet, P., SĖkÈTÈll, A., POUdiOUGO, P., BOAKYE, D., WILSON, M. D. AND BISSAN, Y. 1990. Progress in controlling the reinvasion of windborne vectors into the area of the Onchocerciasis Control Program in West Africa. Phil. Trans. R. Soc. B, 328, 731-750.

BUDOWLE, B., GIUSTI, A. M., WAYE, J. S., BAECHTEL, F. S., FOURNEY, R. M., ADAMS, D. E. ET AL. 1991. Fixed-bin analysis for statistical evaluation of continuous distributions of allelic data from VNTR loci, for use in forensic comparisons. Am. J. Hum. Gen., 48, 841-855.

CHARLESWORTH, B. AND LANGLEY, C. H. 1989. The population genetics of Drosophila transposable elements. Ann. Rev. Genet., 23, 359-383.

COLlins, J. F. AND Coulson, A. F. W. 1987. Molecular sequence comparison and alignment. In: Bishop, M. J. and Rawlings, C. J. (eds) Nucleic Acid and Protein Sequence Analysis: a Practical Approach, pp. 323-358. IRL Press, Oxford and Washington DC.

DEVEREUX, J., HAEbERLl, P. AND SMithies, O. 1984. A comprehensive set of sequence analysis programs for the VAX. Nucl. Acids Res., 12, 387-395.

FLOOK, P. K., WILSON, M. D. AND POST, R. J. 1992. The use of repetitive DNA probes in the analysis of natural populations of insects and parasites. In: Berry, R. J., 
Crawford, T. J. and Hewitt, G. M. (eds) Genes in Ecology, pp. 484-486. British Ecological Society/Blackwell Scientific Publications, Oxford.

FMC-BIOPRODUCTS 1990. How efficient is capillary DNA transfer from high percentage $\mathrm{NuSieve}^{\mathrm{TM}}$ agarose gels. Resolutions, 6, 3-5.

GALE, K. R. AND CRAMPTON, J. 1989. The ribosomal genes of the mosquito, Aedes aegypti. Parasitol. Biochem., 185, $311-317$.

GARMS, R. AND WAl_Sh, J. F. 1987. The migration and dispersal of black flies: Simulium damnosum s.l., the main vector of onchocerciasis in west Africa. In: Kim, K. C. and Merritt, R. W. (eds) Black Flies: Ecology, Population Management and Annotated World List, pp. 341-362. Pennsylvania State University, University Park and London.

JACOBS-LORENA, M., DOMAN, M. AND MAHOWALD, A. 1988. Identification of species specific DNA sequences in North American black flies. Trop. Med. Parasitol., 39, $31-34$.

JEFFREYS, A. J., MACLEOD, A., TAMAKI, K., NEIL, D. L. AND MONCKTON, D. G. 1991. Minisatellite repeat coding as a digital approach to DNA typing. Nature, 354, 204-209.

LE berre, R., WAlsh, J. F., PHILlipon, B., poudiougo, P., HENDERICKX, J. E. E., GUILLET, P. ET AL. 1990. The WHO Onchocerciasis Control Programme: retrospect and prospects. Phil. Trans. R. Soc. B, 328, 721-729.

LOEB, D. D., PADGETT, R. W., hardies, S. C., SHEhEe, W. R., COMER, M. B., EDGELL, M. H. AND HUTCHISON, C. A. 1986. The sequence of a large L1Md element reveals a tandemly repeated $5^{\prime}$ end and several features found in retrotransposons. Mol. Cell. Biol., 6, 168-182.

LYNCH, M. AND CREASE, T. J. 1990. The analysis of population survey data on DNA sequence variation. Mol. Biol. Evol., 7, 377-394.

PHILIPPON, B., REMME, J. H., WALSH, J. F., GUILLET, P. AND ZERBO, D. G. 1990. Entomological results of vector control in the Onchocerciasis Control Programme. Acta Liedensia, 59, 79-94.

POST, R. J. AND FLOOK, P. 1992. DNA probes for the identification of members of the $S$. damnosum complex (Diptera: Simuliidae). Med. Vet. Entomol., 6, 379-384.
POSI, R. J., FLOOK, P. K. AND MILLEST, A. L. 1992. Methods for the preservation of insects for DNA studies. Biochem. Syst. Ecol., 21, 85-92.

RAAB, R. L. AND KENNEDY, G. G. 1980. Movement of Highly Mobile Insects: Concepts and Methodology in Research. North Carolina State University Press, Raleigh.

SAMBROOK, J., FRITSCH, E. F. AND MANIATIS, T. 1989. Molecular Cloning: a Laboratory Manual, 2nd edn, 3 vols. Cold Spring Harbor Laboratory Press, Cold Spring Harbor, NY.

SANGER, F., NIKLEN, S. AND COULSON, A. R. 1977. DNA sequencing with chain terminating inhibitors. Proc. Natl. Acad. Sci. U.S.A., 74, 5463-5467.

SLATKIN, M. 1985. Rare alleles as indicators of gene flow. Evolution, 39, 53-65.

SOUTHERN, E. M. 1975. Detection of specific sequences among DNA fragments separated by gel electrophoresis. J. Mol. Biol., 98, 503-517.

TERZIAN, C. AND BIĖMONT, C. 1988. The founder effect theory: quantitative variation and mdg-1 mobile element polymorphism in experimental populations of Drosophila melanogaster. Genetica, 76, 53-63.

JOWNSON, H., POST, R. J. AND PHILLIPS, A. 1987. Biochemical approaches to black fly taxonomy. In: Kim, K. C. and Merritt, R. W. (eds) Black Flies: Ecology, Population Management and Annotated World List, pp. 24-38. Pennsylvania State University Press, University Park, PA.

WILSON, M. D. AND POST, R. J. 1994. Integration of morphometric, cytogenetic and molecular techniques: A case study of Simulium damnosum. In: Hawksworth, D. L. (ed.) The Identification and Characterisation of Pest Organisms, pp. 215-224. CAB International, Wallingford, UK.

XIONG, B. AND KOCHER, T. D. 1993. Phylogeny of sibling species of Simulium venustum and S. verecundum (Diptera: Simuliidae) based on sequences of the mitochondrial large subunit rRNA gene. Mol. Phylogenet. Evol., 2, 293-303.

YUHKI, N. AND O'BRIEN, S. J. 1990. DNA variation at the major histocompatability complex reflects genomic diversity and population history. Proc. Natl. Acad. Sci. U.S.A., 87, 836-840. 